\title{
Article
}

\section{The Right to Life: Global Evidence on the Role of Security Officers and the Police in Modulating the Effect of Insecurity on Homicide}

\author{
Asongu, Simplice A, Nwachukwu, Jacinta C and Pyke, Chris
}

Available at http://clok.uclan.ac.uk/24355/

Asongu, Simplice A, Nwachukwu, Jacinta C ORCID: 0000-0003-2987-9242 and Pyke, Chris ORCID: 0000-0001-6576-2709 (2019) The Right to Life: Global Evidence on the Role of Security Officers and the Police in Modulating the Effect of Insecurity on Homicide. Social Indicators Research, 143 (2). pp. 727740. ISSN 0303-8300

It is advisable to refer to the publisher's version if you intend to cite from the work. http://dx.doi.org/10.1007/s11205-018-1992-2

For more information about UCLan's research in this area go to http://www.uclan.ac.uk/researchgroups/ and search for <name of research Group>.

For information about Research generally at UCLan please go to http://www.uclan.ac.uk/research/

All outputs in CLoK are protected by Intellectual Property Rights law, including Copyright law. Copyright, IPR and Moral Rights for the works on this site are retained by the individual authors and/or other copyright owners. Terms and conditions for use of this material are defined in the policies page. 
The Right to Life: Global Evidence on the Role of Security Officers and the Police in Modulating the Effect of Insecurity on Homicide

Forthcoming: Social Indicators Research

Simplice A. Asongu

Development Finance Centre, Graduate School of Business,

University of Cape Town Cape Town South Africa.

$\&$

Department of Economics \& Development Studies,

Covenant University, Ota, Ogun State, Nigeria

E-mails: asongusimplice@ yahoo.com / asongus@afridev.org

\section{Jacinta C. Nwachukwu}

Lancashire School of Business and Enterprise, University of Central Lancashire, Preston, PR2 2HE, United Kingdom

Email: j.ch.nwachukwu@gmail.com

\section{Chris Pyke}

Lancashire School of Business and Enterprise, University of Central Lancashire, Preston, PR2 2HE, United Kingdom

Email: cpyke2@uclan.ac.uk 


\begin{abstract}
The study investigates the role of security officers and the police in dampening the effect of insecurity on homicides. Insecurity dynamics are measured in terms of access to weapons, violent crime, perception of criminality and political instability. The geographical and temporal scopes are respectively 163 countries and 2010-2015. The empirical evidence is based on Negative Binomial regressions. Three main findings are established. First, security officers and the police significantly lessen the effect of political instability and perception of criminality on homicides. Second, an extended analysis with thresholds suggest that a maximum deployment of security officers and the police is required in order to completely cancel out the impact of both insecurity dynamics on homicides. The concept of threshold represents the critical mass at which the negative conditional effect from the interaction between security officers and the police completely dampens the effect of insecurity dynamics on homicides. Third, the use of security officers and the police is a necessary but not a sufficient condition for the complete eradication of insecurity-related homicides. Policy implications are discussed.
\end{abstract}

JEL Classification: K42; P50

Keywords: Homicides; Global evidence; security 


\section{Introduction}

The study is motivated by three main concerns in policy and academic circles. They are: (i) the growing rate of homicides around the world, (ii) gaps in the homicides literature and (iii) the policy importance of curtailing the wave of murders. These three issues are expanded in chronological order.

First, consistent with the United Nations Office on Drugs and Crime (UNODC), deaths resulting from homicides around the world are higher than those arising from conflicts and wars (UNODC, 2013). Such a high rate of murder represents a significant threat to the security of civilians. According to the narrative, in the light of the sheer magnitude of the number of lives lost to homicide, policies towards arresting the flow are paramount at the local, national and international levels. This is primarily because the right to life is enshrined both in constitutional and international laws as a supreme normative. Hence, the key obligations of governments and multilateral development institutions is to: (i) protect civilians against unlawful killings, (ii) safeguard the lives of those threatened with murder, (iii) enforce the rule of law through security officers and the police and (iv) assign the responsibility of dealing with homicides to the right jurisdictions within a criminal justice system on time. More specifically, the obligation to protect human life is fundamental in any country's attempt to develop strategies that prevent crime. Theoretically speaking, the positioning of this study on the role of security officers and the police in modulating the effect of insecurity on homicides is of policy relevance in crime prevention.

Second, in accordance with Asongu and Acha-Anyi (2018), recent homicide literature has focused primarily on, inter alia: the consequences for human and social welfare of the interaction of economics with homicides (Bourne et al., 2015); the relationship between homicide and age (Rogers, 2014); a survey of homicide from intimate partners (Stöcklet al., 2013); homicides and violence from cross-national views (Cole \& Gramajo, 2009; Ouimet \& Montmagny-Grenier, 2014); research issues pertaining to homicide and punishment in Europe (Liem \& Campbell, 2014); meta assessments of cross-country homicide predictors (Nivette, 2011); the effects of economic development, income inequality and infant mortality on homicides (Ouimet, 2012); the connection between inequitable distribution of national wealth and homicides in technically-advanced nations (Chamlin \& Cochran, 2006; Jacobs \& Richardson, 2008); global comparative persistence in homicides (Asongu \& Acha-Anyi, 2018) and the relationship between police performance and the rate of homicide (Pare, 2014). This last study in the existing literature is closest to the arguments in this paper. Nevertheless, 
the current study departs from Pare (2014) in three key ways: (i) we use updated panel data for the period 2010 to 2015 instead of data averaged from 1998-2002; (ii) our focus is on 163 countries instead of 77 nations and (iii) the results of our Negative Binomial regressions reflect more causality than those of Pare (2014) which can be interpreted merely as correlations. The findings are also more robust to misspecification errors arising from endogeneous variables because contemporary data on homicides are regressed on noncontemporary security officers and police. Hence our results are more in accord with current international programs on crime prevention than those reported by Pare (2014).

Third, beyond the emphasis on the policy implications of this study as outlined in the first strand above, the international community in the post-2015 SDG agenda is particularly interested in the connection between security, violence and human development within the framework of the rule of law (UNODC, 2013). Accordingly, the damaging effects of homicide could have ramifications beyond the loss of human life because it potentially threatens the wellbeing of the general population by instilling a sense of insecurity and fear. When there are unacceptable levels of killings among a substantial swathe of the population, social cohesion and social capital are significantly undermined. Moreover, as documented by Maggah and Carvalho (2017), the corollaries of homicides in terms of unproductive spending on public and private security and the loss of productivity owing to premature deaths, are stifling the economic development of nations where such murders are prevalent.

By investigating the importance of security officers and the police in controlling the effect of insecurity on homicides, the study responds to topical issues in policy and scholarly circles (articulated in the first and third strands) in order to complement the emerging literature covered in the second strand. Therefore, the objective of the study is twofold, notably to: (i) provide insights into how country-level plans to enhance security through the recruitment of more officers and the police could be implemented in order to lower the number of homicide cases and (ii) assess the existing capacity of the international community to adequately prevent and respond to policy syndrome of homicides ${ }^{1}$. While the first objective is evaluated by quantifying the overall benefits of modulating the effect of insecurity on homicides through security officers and the police, the second objective is examined by calculating thresholds at which the involvement of security officers and the police completely

\footnotetext{
${ }^{1}$ Fosu (2013) defines policy syndromes as situations that are detrimental to growth: 'administered redistribution', 'state breakdown', 'state controls', and 'suboptimal inter temporal resource allocation'. Asongu (2017) considers a policy syndrome as a gap in knowledge economy while Asongu and Nwachukwu (2017) consider it as growth that is not inclusive. Within the context of this study, policy syndrome is referred to as incidences of homicide and circumstances that fuel homicide.
} 
cancels out the harmful effect of insecurity on homicides. Insecurity dynamics are defined from four main perspectives, namely: access to weapons; violent crime; perception of criminality and political instability. Insecurity measurements within the context of this study refer to the various channels that could promote incidents of homicide. The research question which the study aims to answer is stated as follows: "how does the involvement of security officers and the police modulate the effect of insecurity on homicides across the world?"

The theoretical foundation underlying this study is the Wound Culture Theory (WCT). The philosophy that is explored here is that it is the responsibility of security officers and the police to enforce the rule of law and prevent the occurrence of the aforementioned insecurity dynamics (inter alia: access to weapons; violent crime; perception of criminality and political instability) which fuel a wound culture with associated externalities such as homicide.

As articulated by Gibson (2006), the Wound Culture Theory which was first proposed by Mark Seltzer (1998) can be summarized in the following (p. 19):

"Serial killing has its place in a public culture in which addictive violence has become not merely a collective spectacle but one of the crucial sites where private desire and public fantasy cross. The convening of the public around scenes of violence-the rushing to the scene of the accident, the milling around the point of impact-has come to make up a wound culture; the public fascination with torn and open bodies and torn and open persons, a collective gathering around shock, trauma, and the wound".

According to the WCT, the desire to have the human body shattered is harbored by some individuals in society. Such a wish to rip the human body asunder is both figurative (through criticism) and literally (through mutilation). The relevance of serial murder is observed as the communal focus enabling citizens to commit to wound appreciation: "One discovers again and again the excitations in the opening of private and bodily and psychic interiors; the exhibition and witnessing, the endlessly reproducible display of wounded bodies and wounded minds in public. In wound culture, the very notion of sociality is bound to the excitations of the torn and open body, the torn and exposed individual, as public spectacle" (Seltzer, p. 137). Seltzer (p. 21) further observed that the wound culture theory has substantial implications for citizenry attitude formation: "The spectacular public representation of violated bodies, across a range of official, academic, and media accounts, in fiction and in film, has come to function as a way of imagining and situating our notions of public, social, and collective identity." The underlying wound culture which is likely to be fuelled by a policy syndrome of insecurity can intuitively be curbed by security officers and the police in order to enforce law, order and the right to life. 
The rest of the study is structured as follows. Section 2 describes the data and empirical methodology. Section 3 presents the results. We conclude in Section 4 with policy implications and future research directions.

\section{Data and methodology}

In this study, we focus on a panel of 163 countries with data from 2010 to 2015 . The data is obtained from a multitude of sources, namely: a Qualitative assessment by the Economic Intelligence Unit (EIU) analysts' estimates; the Uppsala Conflict Data Program (UCDP) Battle-Related Deaths Dataset; the United Nations Office on Drugs and Crime (UNODC) Surveys on Crime Trends; the Institute for Economics and Peace (IEP); the Operations of Criminal Justice Systems (CTS) and the United Nations Committee on Contributions. The analysis is limited to 2010-2015 due to data availability constraints. The choice of start date is consistent with the evolving homicide literature. This is guided by the desire to provide empirical outcomes which are informed by today's international policy initiatives to combat the various forms of insecurity dynamics (Asongu \& Acha-Anyi, 2018).

The main outcome variable is the number of homicides (per 100,000 people). This mirrors the prevalence of violent crime and deaths in a country. The data on homicide is collectively from the EIC, UNODCand CTS estimates. The main policy variable is the number of security officers and the police (per 100,000 people). Insecurity measurements include the following four policy syndromes: access to weapons, violent crime, perception of criminality and political instability. It is hypothesized that the prevalence of these variables is conducive for murder and homicides. Moreover, they have been used in contemporary literature on conflicts and crimes (Wood, 2015; Mallet, 2015; D'Amico \& Williamson, 2015; Rao et al., 2016; Kopkin, Brodsky, \& DeMatteo, 2017; Wilderman \& Wang, 2017; Olashore, Okanni \& Olashore, 2017; Kjellstrand, 2017).

The four control variables employed in the regression are: the number of armed service personnel (per 100,000 people), the number of people incarcerated (per 100,000 people), the likelihood of violent demonstrations and military expenditure (as a percentage of GDP). From theory, military expenditure and armed service personnel are expected to reduce homicides whereas violent demonstrations and incarcerations should be positively correlated with murders and killings. The selection of these control variables is supported by the literature on the drivers of homicide, violent crimes and conflicts (see Blanco \& Grier, 2009; Freytag,Kruger, Meierrieks, \& Schneider, 2011; Asongu \& Kodila-Tedika, 2016; GPI, 2016; Asongu \& Acha-Anyi, 2018). 
The definitions and sources of variables are presented in Table 1, the summary statistics and list of countries in the study are disclosed in Table 2. Table 3 provides the pairwise correlation matrix which helps notify on the possibility of multicollinearity in variables contained in the conditioning information set. From the descriptive statistics in Table 2, it is obvious that the Means of the variables are comparable. Also, from corresponding variations, we are confident that reasonable relationships will emerge from the regression analyses.

The relatively high correlation between the four policy syndromes is addressed by employing them in distinct specifications. We note that the correlation between the control variables is comparatively low, although the correlation between armed forces personnel and military expenditure is slightly in excess of 0.5 . Similarly, the correlation between policy syndromes and the violent demonstration variable is higher than 0.5. However, Brambor, Clark and Golder, (2006) explain that in interactive regressions such as those employed in this study, the issue of high correlations with potential multicollinearity is normally overlooked. This is because the overall effects are based on the net effects that are computed from estimated unconditional and conditional coefficients.

Table 1: Definitions of variables

\begin{tabular}{ll}
\hline Variables & Definitions of variables and sources \\
\hline Homicides & $\begin{array}{l}\text { Number of homicides per 100,000 people } \\
\text { United Nations Office on Drugs and Crime (UNODC) Surveys on Crime Trends } \\
\text { and the Operations of Criminal Justice Systems (CTS); EIU estimates }\end{array}$ \\
Security Officers \& Police & $\begin{array}{l}\text { Number of internal security officers and police } \\
\text { per 100,000 people UNODC; EIU estimates }\end{array}$ \\
Access to Weapons & Ease of access to small arms and light weapons \\
& Qualitative assessment by EIU analysts \\
Violent crime & Level of violent crime \\
& Qualitative assessment by EIU analysts \\
Perceptions of Criminality & Level of perceived criminality in society \\
& Qualitative assessment by EIU analysts \\
Political instability & Political instability \\
Qualitative assessment by EIU analysts & Number of armed services personnel per 100,000 people \\
Armed Services Personnel & The Military Balance, IISS \\
Incarceration & Number of jailed population per 100,000 people \\
& World Prison Brief, International Centre for Prison Studies, University of Essex \\
Violent demonstrations & Likelihood of violent demonstrations \\
Qualitative assessment by EIU analysts & Military expenditure as a percentage of GDP \\
Military expenditure & The Military Balance, IISS
\end{tabular}

Uppsala Conflict Data Program (UCDP). The Institute for Economics and Peace (IEP).The Economic Intelligence Unit (EIU). United Nations Peacekeeping Funding (UNPKF). GDP: Gross Domestic Product. The International Institute for Strategic Studies (IISS). 
Table 2: Summary Statistics and presentation of countries

\begin{tabular}{llllll} 
& \multicolumn{3}{c}{ Panel A: Summary Statistics } & & \\
Variables & Mean & Standard dev. & Minimum & Maximum & Obsers \\
\hline Homicides & 2.797 & 1.154 & 1.103 & 5.000 & 978 \\
Security Officers \& Police & 2.728 & 0.911 & 1.081 & 5.000 & 978 \\
Access to Weapons & 3.116 & 1.080 & 1.000 & 5.000 & 978 \\
Violent crime & 2.768 & 1.136 & 1.000 & 5.000 & 978 \\
Criminality & 3.153 & 0.917 & 1.000 & 5.000 & 978 \\
Political instability & 2.545 & 1.030 & 1.000 & 5.000 & 978 \\
Armed Services Personnel & 1.648 & 0.725 & 1.000 & 5.000 & 978 \\
Incarceration & 2.194 & 0.889 & 1.150 & 5.000 & 978 \\
Violent demonstrations & 2.912 & 0.969 & 1.000 & 5.000 & 978 \\
Military expenditure & 1.966 & 0.824 & 1.000 & 5.000 & 978 \\
\hline
\end{tabular}

Panel B: Sampled countries (163)

"Afghanistan; Albania; Algeria; Angola; Argentina; Armenia; Australia; Austria; Azerbaijan; Bahrain; Bangladesh; Belarus; Belgium; Benin; Bhutan; Bolivia; Bosnia and Herzegovina; Botswana; Brazil; Bulgaria; Burkina Faso; Burundi; Cambodia; Cameroon; Canada; Central African Republic; Chad; Chile; China; Colombia; Costa Rica; Cote d' Ivoire; Croatia; Cuba; Cyprus; Czech Republic; Democratic Republic of the Congo; Denmark; Djibouti; Dominican Republic; Ecuador; Egypt; El Salvador; Equatorial Guinea; Eritrea; Estonia; Ethiopia; Finland; France; Gabon; Georgia; Germany; Ghana; Greece; Guatemala; Guinea; GuineaBissau; Guyana; Haiti; Honduras; Hungary; Iceland; India; Indonesia; Iran; Iraq; Ireland; Israel; Italy; Jamaica; Japan; Jordan; Kazakhstan; Kenya; Kosovo; Kuwait; Kyrgyz Republic; Laos; Latvia; Lebanon; Lesotho; Liberia; Libya; Lithuania; Macedonia (FYR); Madagascar; Malawi; Malaysia; Mali; Mauritania; Mauritius; Mexico; Moldova; Mongolia; Montenegro; Morocco; Mozambique; Myanmar; Namibia; Nepal; Netherlands; New Zealand; Nicaragua; Niger; Nigeria; North Korea; Norway; Oman; Pakistan; Palestine; Panama; Papua New Guinea; Paraguay; Peru; Philippines; Poland; Portugal; Qatar; Republic of the Congo; Romania; Russia; Rwanda; Saudi Arabia; Senegal; Serbia; Sierra Leone; Singapore; Slovakia; Slovenia; Somalia; South Africa; South Korea; South Sudan; Spain; Sri Lanka; Sudan; Swaziland; Sweden; Switzerland; Syria; Taiwan; Tajikistan; Tanzania; Thailand; The Gambia; Timor-Leste; Togo; Trinidad and Tobago; Tunisia; Turkey; Turkmenistan; Uganda; Ukraine; United Arab Emirates; United Kingdom; United States of America; Uruguay; Uzbekistan; Venezuela; Vietnam; Yemen; Zambia and Zimbabwe”.

Standard dev: standard deviation. Obsers: Observations.

Table 3: Correlation matrix (uniform sample size $=978$ )

\begin{tabular}{|c|c|c|c|c|c|c|c|c|c|c|}
\hline \multirow[b]{2}{*}{ Weapons } & \multicolumn{2}{|c|}{ Policy Syndromes } & \multicolumn{2}{|c|}{ | } & \multicolumn{2}{|c|}{ Control Variables } & \multirow[b]{2}{*}{ Mil Exp. } & \multirow{2}{*}{$\begin{array}{r}\text { Policy V } \\
\text { SOP }\end{array}$} & \multirow{2}{*}{$\begin{array}{c}\text { Dep. V } \\
\text { Homicide }\end{array}$} & \multirow[b]{3}{*}{ Weanons } \\
\hline & Crime & Criminality & Pol. Inst & ASP & Incarce & Demon & & & & \\
\hline \multirow[t]{10}{*}{1.000} & 0.670 & 0.644 & 0.616 & -0.093 & -0.151 & 0.549 & 0.167 & 0.001 & 0.526 & \\
\hline & 1.000 & 0.683 & 0.479 & -0.229 & -0.116 & 0.598 & -0.027 & -0.122 & 0.585 & Crime \\
\hline & & 1.000 & 0.509 & -0.076 & -0.093 & 0.502 & 0.116 & 0.017 & 0.476 & Criminality \\
\hline & & & 1.000 & 0.127 & -0.140 & 0.647 & 0.336 & 0.042 & 0.236 & Pol. Inst. \\
\hline & & & & 1.000 & 0.276 & -0.082 & 0.582 & 0.287 & -0.163 & ASP \\
\hline & & & & & 1.000 & -0.204 & 0.093 & 0.279 & 0.161 & Incarce \\
\hline & & & & & & 1.000 & 0.069 & -0.093 & 0.270 & Demon \\
\hline & & & & & & & 1.000 & 0.215 & -0.098 & Mil. Exp. \\
\hline & & & & & & & & 1.000 & -0.022 & SOP \\
\hline & & & & & & & & & 1.000 & Homicide \\
\hline
\end{tabular}

Weapons: Access to weapons. Crime: Violent crime. Criminality: Perceptions of criminality. Pol. Inst: Political instability. ASP: Armed Service Personnel. Incarce: Incarcerations. Demon: Violent demonstrations. Mil Exp : Military Expenditure. SOP : Security Officers and Police. Policy V: Policy Variable. Dep. V: Dependent Variable. 55\% critical value (two-tailed) $=0.0627$ for $n=978$. 


\subsection{Methodology}

Given the positive skewness in the data, a negative binomial regression is employed in accordance with the latest literature on positively-skewed outcome variables (Choi\& Luo, 2013; Choi, 2015). In a negative binomial regression, the mean of the outcome variable y is determined by the exposure time $t$ and a set of $k$ explanatory variables (the $x$ 's). The empirical expression relating these quantities is:

$\mu_{i}=\exp \left(\ln \left(t_{i}\right)+\beta_{1} x_{1 i}+\beta_{2} x_{2 i}+\cdots+\beta_{\mathrm{k}} x_{\mathrm{k} i}\right)$,

where, $x_{1} \equiv 1$ and $\beta_{1}$ is the intercept. The symbols $\beta_{1}, \beta_{2}, \ldots, \beta_{\mathrm{k}}$ correspond to unknown parameters to be estimated. Their estimates are symbolized as $b_{1}, b_{2}, \ldots, b_{k}$. The fundamental negative binomial regression model for an observation $i$ is written as:

$\operatorname{Pr}\left(Y=y_{i} \mid \mu_{i}, \alpha\right)=\frac{\Gamma\left(y_{i}+\alpha^{-1}\right)}{\Gamma\left(\alpha^{-1}\right) \Gamma\left(y_{i}+1\right)}\left(\frac{1}{1+\alpha \mu_{i}}\right)^{\alpha^{-1}}\left(\frac{\alpha \mu_{i}}{1+\alpha \mu_{i}}\right)^{y_{i}}$,

where, $\mu_{i}=t_{i} \mu$ and $\alpha=\frac{1}{v}$ in the generalised Poisson distribution which includes a gamma noise variable with a Mean of 1 and a scale of $v$. The parameter $\mu$ represents the Mean incidence rate of $y$ per unit of exposure or time. Hence, $\mu$ is the risk of a new occurrence of the event during a specified exposure period, $\mathrm{t}$ (NCSS, 2017). Consistent with the literature (Choi \& Luo, 2013; Choi, 2015; Mlachila, Tapsoba \& Tapsoba, 2017; Asongu, Anyanwu, \& Tchamyou, 2017a), the explanatory variables are lagged by one year in order to correct for potential endogeneity bias.

\section{Empirical results}

Table 4 presents the results of our negative binomial regressions. Whereas the first panel involves regressions without a conditioning information set, the second includes control variables.

We recall that the first aim of this study is to assess the significance of security officers and the police in modulating the damaging influence of insecurity on homicides. To this end, we computed the net effects and thresholds of these two policy tools along the lines suggested by Tchamyou (2018) and Tchamyou and Asongu (2017). For example, in Column 4 of Table 4 , the net effect calculated from the interception of security officers and the police on the perception of criminality is 0.209 (i.e., [-0.068 2.728$]+[0.395]$ ), where: 0.395 is the unconditional effect from the perception of criminality; 2.728 is the Mean value of security 
officers and police and -0.068 is the conditional effect of the interaction between the "perception of criminality" with "security officers and police".

The second objective is to investigate the robustness of existing international security arrangements in preventing and nullifying the consequences of homicide occurrences. This aim is assessed by computing thresholds at which security officers and the police completely wipe out the destructive impact of insecurity on homicides.

\section{Table 4:Negative binomial regressions}

\begin{tabular}{|c|c|c|c|c|c|c|c|c|}
\hline \multirow[b]{3}{*}{ Constant } & \multicolumn{8}{|c|}{ Dependent variable: Homicides } \\
\hline & \multicolumn{4}{|c|}{ Without control variables } & \multicolumn{4}{|c|}{ With control variables } \\
\hline & $\begin{array}{l}0.137 \\
(0.525)\end{array}$ & $\begin{array}{l}0.160 \\
(0.382)\end{array}$ & $\begin{array}{l}-0.265 \\
(0.282)\end{array}$ & $\begin{array}{l}0.513 * * * \\
(0.000)\end{array}$ & $\begin{array}{l}0.144 \\
(0.532)\end{array}$ & $\begin{array}{l}0.109 \\
(0.577)\end{array}$ & $\begin{array}{l}-0.357 \\
(0.182)\end{array}$ & $\begin{array}{l}0.386 * \\
(0.067)\end{array}$ \\
\hline Security Officers \& Police(SOP)(-1) & $\begin{array}{l}0.081 \\
(0.284)\end{array}$ & $\begin{array}{l}0.093 \\
(0.134)\end{array}$ & $\begin{array}{l}0.226 * * * \\
(0.008)\end{array}$ & $\begin{array}{l}0.105 \\
(0.136)\end{array}$ & $\begin{array}{l}0.025 \\
(0.746)\end{array}$ & $\begin{array}{l}0.082 \\
(0.200)\end{array}$ & $\begin{array}{l}0.196 * * \\
(0.024)\end{array}$ & $\begin{array}{l}0.075 \\
(0.294)\end{array}$ \\
\hline Access to Weapons(-1) & $\begin{array}{l}0.271 * * * \\
(0.000)\end{array}$ & --- & -- & --- & $\begin{array}{l}0.259 * * * \\
(0.000)\end{array}$ & --- & -- & -- \\
\hline Violent Crime(-1) & -- & $\begin{array}{l}0.269 * * * \\
(0.000)\end{array}$ & --- & --- & -- & $\begin{array}{l}0.282 * * * \\
(0.000)\end{array}$ & --- & --- \\
\hline Perceptions of Criminality(-1) & --- & -- & $\begin{array}{l}0.395 * * * \\
(0.000)\end{array}$ & --- & --- & -- & $\begin{array}{l}0.372 * * * \\
(0.000)\end{array}$ & --- \\
\hline Political Instability(-1) & --- & --- & -- & $\begin{array}{l}0.190 * * * \\
(0.001)\end{array}$ & --- & --- & -- & $\begin{array}{l}0.157 * * \\
(0.015)\end{array}$ \\
\hline Access to Weapons×SOP(-1) & $\begin{array}{l}-0.024 \\
(0.242)\end{array}$ & --- & --- & -- & $\begin{array}{l}-0.010 \\
(0.624)\end{array}$ & --- & --- & --- \\
\hline Violent Crime $(-1) \times \operatorname{SOP}(-1)$ & -- & $\begin{array}{l}-0.021 \\
(0.251)\end{array}$ & --- & --- & --- & $\begin{array}{l}-0.024 \\
(0.221)\end{array}$ & --- & --- \\
\hline Perceptions of Criminality $\times \operatorname{SOP}(-1)$ & --- & --- & $\begin{array}{l}-0.068 * * * \\
(0.004)\end{array}$ & --- & --- & --- & $\begin{array}{l}-0.062 * * \\
(0.012)\end{array}$ & --- \\
\hline Political Instability×SOP(-1) & --- & --- & -- & $\begin{array}{l}-\mathbf{0 . 0 3 8} * \\
(0.088)\end{array}$ & --- & --- & -- & $\begin{array}{l}-0.026 \\
(0.249)\end{array}$ \\
\hline Armed Services Personnel(-1) & --- & --- & --- & --- & $\begin{array}{l}-0.051 \\
(0.194)\end{array}$ & $\begin{array}{l}-0.036 \\
(0.352)\end{array}$ & $\begin{array}{l}-0.068 * \\
(0.081)\end{array}$ & $\begin{array}{l}-0.117 * * * \\
(0.003)\end{array}$ \\
\hline Incarceration(-1) & --- & --- & --- & --- & $\begin{array}{l}0.132 * * * \\
(0.000)\end{array}$ & $\begin{array}{l}0.101 * * * \\
(0.000)\end{array}$ & $\begin{array}{l}0.124 * * * * \\
(0.000)\end{array}$ & $\begin{array}{l}0.128 * * * * \\
(0.000)\end{array}$ \\
\hline Violent demonstrations(-1) & --- & --- & --- & --- & $\begin{array}{l}0.010 \\
(0.689)\end{array}$ & $\begin{array}{l}-0.013 \\
(0.627)\end{array}$ & $\begin{array}{l}0.044 * \\
(0.084)\end{array}$ & $\begin{array}{l}0.074 \\
(0.011)\end{array}$ \\
\hline Military Expenditure (-1) & --- & --- & --- & --- & $\begin{array}{l}-0.092 * * * \\
(0.006)\end{array}$ & $\begin{array}{l}-0.033 \\
(0.300)\end{array}$ & $\begin{array}{l}-0.054 * \\
(0.093)\end{array}$ & $\begin{array}{l}-0.053 \\
(0.118)\end{array}$ \\
\hline Net Effect & na & na & 0.209 & 0.086 & na & na & 0.202 & na \\
\hline Threshold & na & na & 5.808 & 5.000 & na & na & 6.000 & na \\
\hline Log likelihood & -1296.652 & -1285.901 & -1305.715 & -1339.818 & -1274.628 & -1275.135 & -1288.291 & -1314.974 \\
\hline Likelihood Ratio (LR) Chi-Square & $111.23 * * *$ & $132.73 * * *$ & $93.11 * * *$ & $24.90 * * *$ & $155.28 * * *$ & $154.26 * * *$ & $127.95 * * *$ & $74.59 * * *$ \\
\hline Likelihood Ratio (LR) for Lnalpha & $-\overline{33.673 * * *}$ & $-\overline{33.673 * * *}$ & 33.673*** & $-\overline{33.673 * * *}$ & - $33.673 * * *$ & - $33.673 * * *$ & $127.95 * * *$ & - \\
\hline Observations & 815 & 815 & 815 & 815 & 815 & 815 & 815 & 815 \\
\hline
\end{tabular}

The result in Column 4 indicate that given that the unconditional effect of "perception of criminality" is positive and the conditional interactive effect is negative, the critical mass or 
threshold at which the unconditional positive effect of "perception on criminality" is completely neutralised by security officers and the police is $5.808(0.395 / 0.068)$. Unfortunately, the computed threshold has less economic relevance because it is not within the range (minimum to maximum) of security officers and police disclosed in the summary statistics $^{2}$. This implies that more policy initiatives aimed at completely removing the damaging influence of insecurity on homicides (by involving security officers and the police) are required. More specifically, the results confirm that while there will always be insecurityrelated killings and murders, the deployment of security officers and the police is a necessary not a sufficient condition for a total eradication of insecurity-inspired homicides. Nonetheless, the negative unconditional effect implies that the involvement of security officers and the police significantly lowers the impact of "political instability" and "perception of criminality" on homicides. The threshold related to political instability is within policy range because it reflects the maximum value disclosed in Table 2 for summary statistics. The economic significance of this estimated cut-off point is that a full deployment of security officers and the police is required to reduce the effect of insecurity dynamics on homicides.

The notion that threshold levels represent the critical masses at which the negative conditional effect from the interaction between security officers and the police completely cancels the effect of insecurity dynamics on homicides is supported by evidence in the literature. They comprise studies on: (i) thresholds for favourable impacts (Cummins, 2000) and requirements essential for U-shaped and inverted U-shaped relationships (Roller \& Waverman, 2001; Batuo, 2015); (ii) thresholds at which information and communication technology enhances environment sustainability (Asongu, le Roux, \& Biekpe,2018a), inclusive human development (Asongu \& le Roux, 2017) and mitigates the damaging effect of environmental degradation on inclusive development (Asongu, le Roux, \& Biekpe, 2017b), and (iii) essential information sharing thresholds in the mitigation of information asymmetry for financial access (Asongu, le Roux, \& Tchamyou, 2018b). Our finding on the significance of the role of security and police officers in reducing insecurity-related homicides is broadly supported by Pare (2014).

The statistical significance of the control variables displays the expected signs. For instance, as expected, "armed service personnel" and military expenditure have a negative

\footnotetext{
${ }^{2}$ It is important to note that while the security officers and police are per 100, 000 people, the values are coded on a 1 to 5 scale according to the level of security. Moreover, security officers and police within this context refer to civil police force as distinct from local militia and national guards.
} 
effect on homicides while incarcerations and violent demonstrations are positively associated with it.

\section{Concluding implications and future research directions}

The study investigated the relevance of the involvement of security officers and the police in preventing and dampening the destructive effect of insecurity on homicides. Insecurity is measured in terms of four policy syndromes: access to weapons, violent crime, perception of criminality and political instability. The geographical and temporal possibilities are limited respectively to 163 countries and 2010-2015. Two major findings are confirmed from eight negative binomial regressions with or without control variables. They are:

First, security officers and the police significantly lower the potential harmful effect of "political instability" and "perception of criminality" on homicides. Second, while the estimated net effect on homicide of the deployment of security officers and the police is positive, the threshold at which their involvement is predicted to completely nullify the influence of political instability on homicides is the only estimate that is practically viable. This is because the implied cut-off point for the number of security officers and the police needed to completely wipe out the consequences of political instability on homicide occurrences is within the maximum values observed in the countries of study. The economic interpretation of the estimated cut-off points is that a full deployment of security officers and the police is needed to weaken the effect of insecurity dynamics on homicides. Then too, the fact that the computed thresholds are considerably higher than the historical average values observed for the countries of study is a further indication that the contribution of security officers and the police need to be complemented with other policy initiatives in order to completely stem the wave of insecurity-related homicides. The following policy recommendations are noteworthy.

In tackling homicides relating to insecurity dynamics (i.e. access to weapons, violent crime, political instability and perception of criminality), security officers and the police are discouraged from using repressive actions. It follows from our findings that suppressive tactics by the authorities are most likely to be counter-productive if not complemented with additional strategies which assuage the influence of the other determinants of homicide and insecurity. These extra policy initiatives should be designed to deal with concerns about youth education and employment, socio-economic inequalities and access to public goods and services. These may include measures which: (i) encourage the use of new information and communications technologies in youth education and crime prevention campaigns. Such 
interactive methods should ensure that the various stakeholders in society are more conscious of the connection between homicide and general wellbeing; (ii) localise crime preventive programs and specifically target known hotspots for violence and homicides in the area; (iii) emphasise the importance of gun control and the effects of income inequality and drug use on homicides and (vi) underscore the proliferation of cybercrime and its implications for homicides.

Future research directions should focus on individual country case studies in order to identify more targeted country-oriented homicide determinants and their solutions. Moreover, the findings here show that the involvement of security officers and the police is necessary but not a sufficient condition for the complete eradication of insecurity-related homicides. Consequently, an assessment of the complementary policy tools which enhances the role of security officers and the police in preventing and nullifying the effect of insecurity dynamics on homicides is worthwhile.

\section{References}

Ashraf, Q., \& Galor, O., (2013). "The Out of Africa Hypothesis, Human Genetic Diversity, and Comparative Economic Development".American Economic Review, 103(1), pp. 1-46.

Asongu, S. A., (2017). "Knowledge Economy Gaps, Policy Syndromes and Catch-up Strategies: Fresh South Korean Lessons to Africa", Journal of the Knowledge Economy, 8(1), pp. 211-253.

Asongu, S. A., (2018). "Persistence in Incarcerations: Global Comparative Evidence”, Journal of Criminological Research, Policy and Practice.DOI: 10.1108/JCRPP-11-2017-0037.

Asongu, S. A., \&Acha-Anyi, P. N., (2018). "The Murder Epidemic: A Global Comparative Study”, International Criminal Justice Review. DOI: 10.1177/1057567718759584.

Asongu, S. A., Anyanwu, J. C., \&Tchamyou, V. S., (2017a). "Technology-driven information sharing and conditional financial development in Africa", Information Technology for Development, DOI: 10.1080/02681102.2017.1311833.

Asongu, S. A., \& Kodila-Tedika, O., (2016). "Fighting African conflicts and crimes: which governance tools matter?",International Journal of Social Economics, 43(5), pp. 466-485.

Asongu, S. A., \& le Roux S., (2017). "Enhancing ICT for inclusive human development in Sub-Saharan Africa", Technological Forecasting and Social Change, 118(May), pp. 44-54.

Asongu, S. A., le Roux, S., \& Biekpe, N., (2017b). "Environmental degradation, ICT and inclusive development in Sub-Saharan Africa", Energy Policy, 111(December), pp. 353-361. 
Asongu, S. A., le Roux, S., \& Biekpe, N., (2018a). "Enhancing ICT for Environmental Sustainability in Sub-Saharan Africa", Technological Forecasting and Social Change, 127(February), pp. 209-216.

Asongu, S. A., Le Roux, S., \& Tchamyou, V. S., (2018b). "Essential Information Sharing Thresholds for Reducing Market Power in Financial Access: A Study of the African Banking Industry", Journal of Banking Regulation.DOI: 10.1057/s41261-018-0065-4.

Asongu, S. A., \& Nwachukwu, J. C., (2017)."Quality of Growth Empirics: Comparative Gaps, Benchmarking and Policy Syndromes”, Journal of Policy Modeling, 39(5), pp.861-882.

Batuo, M. E., (2015). "The role of telecommunications infrastructure in the regional economic growth of Africa", Journal of Development Areas, 49(1), pp. 313-330.

Blanco, R., \& Grier, B., (2009). "Long Live Democracy: The Determinants of Political Instability in Latin America", The Journal of Development Studies, 45(1), pp. 76-95.

Bourne, P. A., Hudson-Davis, A., Sharpe-Pryce, C., Francis, C., Solan, I., Lewis, D., Quarrie, V. L., Pabarue, M., Nelson, S., Irving, S., \& Anderson, H., (2015). "The Effects of Homicides and Economics on Human and Social Biology: A Mental Health Challenge for a Society?",International Journal of Emergency Mental Health and Human Resilience, 17(2), pp. 495-501.

Brambor, T., Clark, W. M., and Golder, M., (2006). "Understanding Interaction Models: Improving Empirical Analyses”, Political Analysis, 14 (1), pp. 63-82.

Chamlin M. B.,\& Cochran J. K. (2006). "Economic inequality, legitimacy, and cross-national homicide rates".Homicide Studies, 10, pp. 231-252.

Choi, S-W., (2015). "Economic growth and terrorism: domestic, international, and suicide", Oxford Economic Papers, 67(1), pp. 157-181.

Choi, S-W., \& Luo, S., (2013). "Economic Sanctions, Poverty, and International Terrorism: An Empirical Analysis," International Interactions, 39(2), pp.217-245.

Cole J. H.,\&Gramajo A. M. (2009). "Homicide rates in a cross-section of countries: Evidence and interpretations”. Population and Development Review, 35, pp.749-776.

Cummins, J. (2000). Language, power and pedagogy: Bilingual children in the crossfire. Clevedon, England: Multilingual Matters.

D’Amico, D. J., \& Williamson, C., (2015). "Do legal origins affect cross-country incarceration rates?",Journal of Comparative Economics, 43(3), pp. 595-612.

Fosu, A., (2013), "Growth of African Economies: Productivity, Policy Syndromes and the Importance of Institutions”, Journal of African Economies, 22(4), pp. 523-551.

Freytag, A., Kruger, J. J., Meierrieks, D., \& Schneider, F., (2011).“The origins of terrorism: Cross-country estimates of socio-economic determinants of terrorism", The European Journal of Political Economy, 27(Supplement 1), pp. S5-S16. 
Gibson, D. C., (2006). "The Relationship Between Serial Murder and the American Tourism Industry", Journal of Travel \& Tourism Marketing, 20(1), pp. 45-60.

GPI (2016).Global Peace Index 2016. Institute for Economics \& Peace. http://visionofhumanity.org/app/uploads/2017/02/GPI-2016-Report_2.pdf(Accessed: 23/07/2016).

Jacobs D., \& Richardson A. M. (2008)."Economic inequality and homicide in the developed nations from 1975 to 1995 ".Homicide Studies, 12, pp.28-45.

Kjellstrand, K., (2017). "Building a Tailored, Multilevel Prevention Strategy to Support Children and Families Affected by Parental Incarceration", Journal Smith College Studies in Social Work, 87(1), pp. 112-129.

Kopkin, M. R., Brodsky, S. L., \&DeMatteo, D., (2017). "Risk assessment in sentencing decisions: a remedy to mass incarceration?",Journal of Aggression, Conflict and Peace Research, 9(2), pp.155-164.

Liem, M., \& Campbell, M., (2014). "Punishment for Homicide in Europe: Research Challenges and a Roadmap for Progress", International Criminal Justice Review, 24(3), pp. 285-297.

Mallet, C. A., (2015)."The incarceration of seriously traumatised adolescents in the USA: Limited progress and significant harm", Criminal Behavior and Mental Health, 25(1), pp. 1-9.

Mlachila, M., Tapsoba, R., \&Tapsoba, S. J. A., (2017). “A Quality of Growth Index for Developing Countries: A Proposal”, Social Indicators Research,134(2), pp 675-710.

Muggah, R., \& de Carvalho, I. S., (2017). “There's a cure for Latin America's murder epidemic - and it doesn't involve more police or prisons", World Economic Forum, https://www.weforum.org/agenda/2017/04/there-s-a-cure-for-latin-america-s-murderepidemic-and-it-doesn-t-involve-more-police-orprisons/?utm_content=buffer $369 \mathrm{bb} \& u t m \_$medium $=$social\&utm_source=plus.google.com\&ut m_campaign=buffer (Accessed: 28/07/2017).

NCSS (2017). "Negative Binomial Regression", NCSS Statistical Software, https://ncss-wpengine.netdna-ssl.com/wpcontent/themes/ncss/pdf/Procedures/NCSS/Negative_Binomial_Regression.pdf (Accessed: 16/05/2017).

Nivette A. E. (2011). "Cross-national predictors of homicide: A meta-analysis". Homicide Studies, 15, pp. 103-131.

Olashore, A. A., Okanni, O. O., \&Olashore, O. O., (2017). "Associate Factors of Delinquency Among Incarcerated Male Juveniles in a Borstal Institution in Nigeria", Journal International Journal of Forensic Mental Health, DOI: 10.1080/14999013.2017.1288668.

Ouimet M., (2012). "A world of homicides: The effect of economic development, income inequality, and excess infant mortality on the homicide rate for 165 countries in 2010". Homicide Studies, 16, pp. 238-258. 
Ouimet, M., \&Montmagny-Grenier, C., (2014). "Homicide and Violence-International and Cross-National Research", International Criminal Justice Review, 24(3), pp. 222-234.

Pare, P-P., (2014). "Indicators of Police Performance and Their Relationships With Homicide Rates Across 77 Nations”, International Criminal Justice Review, 24(3), pp. 254-270.

Rao, R., Mandal, P., Gupta, R., Ramshankar, P., Mishra, A., Ambekar, A., Jhanjee, S., \&Dhawan, J., (2016). "Factors Affecting Drug Use During Incarceration: A Cross-Sectional Study of Opioid-Dependent Persons from India", Journal of Substance Abuse Treatment, 61(February), pp. 13-17.

Rogers, M., (2014). "A Descriptive and Graphical Analysis of the (Lack of) Association Between Age and Homicide Cross-Nationally", International Criminal Justice Review, 24(3), pp. 235-253.

Roller, L-H., \&Waverman, L. (2001)."Telecommunications infrastructure and economic development: a simultaneous approach", American Economic Review, 91(4), pp. 909-923.

Seltzer, M. (1998). Serial killers: Death \& life in America's wound culture. NY: Routledge.

Stöckl, H., Devries, K., Rotstein, A. Abrahams, N., Campbell, J., Watts, C., \& Moreno, C. G., (2013). “The global prevalence of intimate partner homicide: a systematic review", The Lancet, 382(9895), pp. 859-865.

Tchamyou, V. S., (2018). "Education, Lifelong learning, Inequality and Financial access: Evidence from African countries”, Contemporary Social Science. DOI: 10.1080/21582041.2018.1433314.

Tchamyou, V. S., \&Asongu, S. A., (2017).“Information Sharing and Financial Sector Development in Africa”, Journal of African Business, 18(1), pp. 24-49.

UNODC(2013). "Global Study on Homicide : Trends, Context and Data", United Nations Office on Drugs and Crime.

https://www.unodc.org/documents/data-andanalysis/statistics/GSH2013/2014_GLOBAL_HOMICIDE_BOOK_web.pdf (Accessed: $15 / 02 / 2018)$.

Wilderman, C., \& Wang, A. W., (2017)."Mass incarceration, public health, and widening inequality in the USA", The Lancet, 389(10077), pp. 1464-1474.

Woods, W. R., (2015). "Why Restorative Justice Will Not Reduce Incarceration”, Br J Criminol,55 (5), pp. 883-900. 